\title{
The Workload of Female Workers Has Very Little Effect On Career Development
}

\author{
Mochamad Mochklas ${ }^{1}$, Didin Fatihudin ${ }^{2}$ \\ $\left\{\right.$ mmochklas@gmail.com $\left.{ }^{1}\right\}$ \\ Faculty of Economics and Business, University of Muhammadiyah Surabaya ${ }^{1,2}$
}

\begin{abstract}
Continuous career development is the benchmark of employees in showing their performance optimally, on the other hand the workload of female workers makes them feel unsure of their competence to develop careers. This study aims to analyze the effect of workload of female workers on career development. The sample of this study was 250 female workers in the coral industry area of Surabaya with the classification of employees with income that was regional minimum wages. Data entered and can be processed are 248 female workers. The results of research data analysis show that workload has a significant positive direct effect on career development. Because it is necessary for companies to have career development programs that encourage employees to improve performance in work.
\end{abstract}

Keywords: Workload, Career Development, Female Workers

\section{Introduction}

The results of the 2016 Census of the Economy, the number of companies in Indonesia was recorded at 26.7 million, this figure increased by $17.51 \%$ compared to the results of the 2006 Economic Census of 22.7 million companies. There are 3.98 million new companies in the last 10 years, the company generally operates in the sectors of Large Trade and Retail, Repair and Maintenance of Cars and Motorbikes as much as 12.3 million or $46.17 \%$, business fields of Provision of Accommodation and Provision of Drinking Foods $16,72 \%$ and Processing Industry $16.53 \%$. The women's labor force participation rate increased by 2.33 percent to 55.04 percent from the previous one, 52.71 percent in February 2016 [1].

With the increasing number of companies, the supply of human resources that are ready to work in the industrial sector is experiencing a shortage. Every year the industrial sector requires skilled human resources. On the other hand, every year there are around $10-12 \%$ of employees who make turnover [2]. Career development is basically oriented towards the development of the company can answer business challenges in the future. Career development is an employee's personal efforts to achieve a career plan [3]. Effective career development is important for employees and organizations in achieving goals, career development influences Employee Engagement [4], job satisfaction [5], employee performance [6]. 
There are demands for organizational human resources to provide assistance in the form of various interventions in career development activities. attitudes towards career development between male employees and female employees are the same [7]. Career development can be optimized through improving education, competence and work performance [8].

Workload will be felt for individuals who lack the ability in the field of work that is being occupied or the number of jobs that cannot be completed on time [9]. The main obstacle in developing a career is often a problem that is not fully realized by employees. Many employees complain that their careers do not move better by blaming workload. Workload influences employee job satisfaction [5], excessive workload influences employee turnover [10]. There is a significant positive relationship between perceptions of workload and turnover intention on employees [2], there is a relationship between mental workload and work stress in [11].

This study aims to analyze the effect of workload on the development of factory worker careers. By knowing the effect of workload on career development, it can provide input to companies in improving the organization's human resources to provide assistance in the form of various interventions in career development activities.

\section{Study of Literature}

\subsection{Career development}

Career is the whole position that can be occupied by someone during his working life in the company. From the point of view of factory workers, position is a very important thing because everyone wants a position that is in accordance with his wishes and wants the highest position possible according to his ability. Career development is a personal improvement that a person makes to achieve a career plan [3].

In addition to the role of individuals, managers, and organizations in career development, there are a variety of more specific factors that influence career development, there are seven factors that influence someone's career development, among others: Satisfactory work performance from what is entrusted to him, Introduction by the party others, loyalty to the organization, mentors and sponsors, support from subordinates, opportunities to grow, and stopping at the request and will of their own [12].

\subsection{Workload}

In increasing employee work productivity, one aspect that must be considered by each company is Workload. Excessive workload will result in bad effects, which will lead to physical and mental fatigue and emotional reactions such as headaches, digestive disorders, and irritability. While the workload is too little where the work that occurs because of reduced motion will cause boredom.

The work ability of each employee is different from one another, this is very dependent on the level of skills, physical fitness, age and body size of the workers themselves. Workload consists of three factors, namely the burden of time, namely the amount of time available in carrying out a job, mental load that is the amount of mental effort in carrying out a job, and psychological burden that shows the level of work risk, confusion and frustration [13]. 


\section{$3 \quad$ Research Method}

The conceptual framework of this research departs from the workload of factory workers in their main tasks with high workloads causing their career to grow in the company unable to develop. In addition, a high workload also causes a reduction in the time that factory workers can use to improve their ability to complete the work themselves.

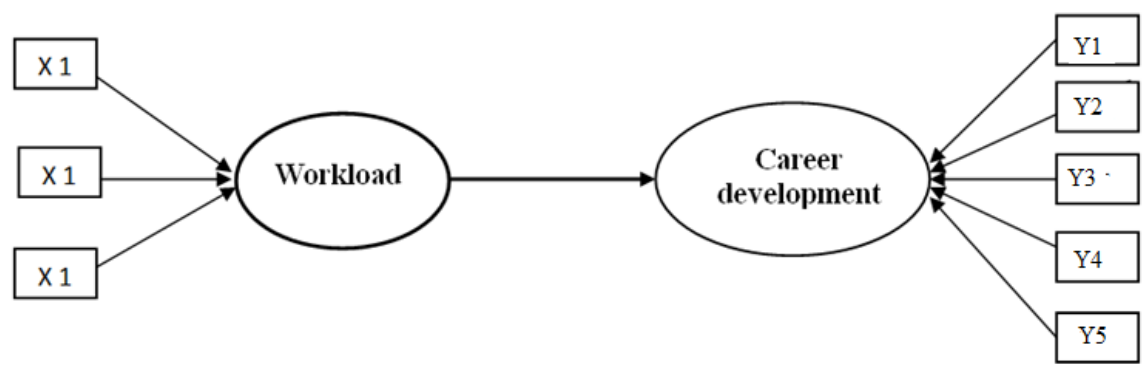

Fig 1. Conceptual Framework

Population is a generalization area, subject that has certain qualities and characteristics determined by researchers to be studied and then conclusions are drawn [14]. The population in this study were female workers in the coral industrial estate in Surabaya. The sample characteristics of this study were female workers with regional minimum wages, where the number of sample data entered and could be processed was 248 .

\section{$4 \quad$ Results and discussion}

\subsection{Results}

\section{Analysis of Research Variable Descriptions}

Description analysis is an analysis that describes the perceptions of respondents' answers to statement items on research variables in the questionnaire distributed to respondents. The description of the workload variable (X) consists of 3 statements, in which all statements are scored with an ordinal scale with a minimum score of 1 and the maximum score is 5 , as shown in table 1.

Based on table 1, it can be seen as follows that the respondent's response to item 1, can be explained as follows: 5 respondents (1.89\%) stated disagree, 37 respondents $(15.09 \%)$ stated disagree, 206 respondents $(83,02 \%)$ agree and strongly agree, with an average value of 4.019. The results of the average score indicate that to meet the company's targets female workers are required to work overtime. 
Table 1. Respondents' Response to Workload

\begin{tabular}{lcccccc}
\hline \multicolumn{1}{c}{ Statement } & $\begin{array}{c}\text { Strongly } \\
\text { Disagree }\end{array}$ & Disagree & Doubtful & Agree & $\begin{array}{c}\text { Strongly } \\
\text { Agree }\end{array}$ & Mean \\
\hline $\begin{array}{l}\text { To meet the company's } \\
\text { target, I am required to work } \\
\text { overtime }\end{array}$ & $0,00 \%$ & $1,89 \%$ & $15,09 \%$ & $62,26 \%$ & $20,75 \%$ & 4,019 \\
$\begin{array}{l}\text { In completing work } \\
\begin{array}{l}\text { according to the SOP, I was } \\
\text { required to work with full } \\
\text { concentration }\end{array}\end{array}$ & $0,00 \%$ & $3,77 \%$ & $18,87 \%$ & $64,15 \%$ & $13,21 \%$ & 3,868 \\
$\begin{array}{l}\text { In order to avoid being } \\
\text { terminated, I work more } \\
\text { seriously }\end{array}$ & $0,00 \%$ & $3,77 \%$ & $22,64 \%$ & $50,94 \%$ & $22,64 \%$ & 3,925 \\
\hline
\end{tabular}

Respondents on item 2, can be explained as follows: 9 respondents (3.77\%) expressed disagreement, 47 respondents (18.87\%) stated disagreement, 192 respondents $(77.36 \%)$ agreed and strongly agreed, with an average value of 3.868. The average score shows that in completing work according to the SOP, female workers are required to work with full concentration.

Respondents on item 3, can be explained as follows: 10 respondents (3.77\%) stated disagreement, 56 respondents (22.64\%) stated disagreement, 182 respondents $(73.58 \%)$ agreed and strongly agreed, with an average value of 3,925. The average value of the results shows that in order to avoid layoff sanctions, female workers will work more seriously.

Table 2. Respondents' Responses to Career Development

\begin{tabular}{lcccccc}
\hline \multicolumn{1}{c}{ Statement } & $\begin{array}{c}\text { Strongly } \\
\text { Disagree }\end{array}$ & Disagree & $\begin{array}{c}\text { Score } \\
\text { Doubtful }\end{array}$ & $\begin{array}{c}\text { Agree } \\
\text { Strongly } \\
\text { agree }\end{array}$ & Mean \\
\hline $\begin{array}{l}\text { The company will give } \\
\text { rewards to employees who } \\
\text { have good work } \\
\text { performance }\end{array}$ & $0,00 \%$ & $11,32 \%$ & $9,43 \%$ & $35,85 \%$ & $43,40 \%$ & 4,113 \\
$\begin{array}{l}\text { Companies provide space } \\
\text { for employees to develop } \\
\text { creativity in completing } \\
\text { work }\end{array}$ & $1,89 \%$ & $9,43 \%$ & $20,75 \%$ & $54,72 \%$ & $13,21 \%$ & 3,679 \\
$\begin{array}{l}\text { The company gives trust to } \\
\text { employees in completing }\end{array}$ & $0,00 \%$ & $1,89 \%$ & $13,21 \%$ & $50,94 \%$ & $33,96 \%$ & 4,17 \\
work & & & & & & \\
\end{tabular}




\begin{tabular}{lcccccc}
\hline \multicolumn{1}{c}{ Statement } & $\begin{array}{c}\text { Strongly } \\
\text { Disagree }\end{array}$ & Disagree & $\begin{array}{c}\text { Score } \\
\text { Doubtful }\end{array}$ & $\begin{array}{c}\text { Agree } \\
\text { Strongly } \\
\text { agree }\end{array}$ & Mean \\
\hline $\begin{array}{l}\text { To improve the career of } \\
\text { the company, encourage } \\
\begin{array}{l}\text { all employees to work } \\
\text { properly }\end{array}\end{array}$ & $0,00 \%$ & $5,66 \%$ & $15,09 \%$ & $26,42 \%$ & $52,83 \%$ & 4,264 \\
$\begin{array}{l}\text { The company provides } \\
\text { opportunities for } \\
\text { advancing opportunities } \\
\text { for all employees }\end{array}$ & $1,89 \%$ & $0,00 \%$ & $7,55 \%$ & $58,49 \%$ & $32,08 \%$ & 4,189 \\
\hline
\end{tabular}

Based on table 2, it can be seen as follows that the responses of respondents on item 1, can be explained as follows: 28 respondents (11.32\%) stated disagree, 23 respondents $(9.43 \%)$ stated disagreement, 197 respondents $(79,25 \%)$ agree and strongly agree, with an average value of 4,113 . The results of the average value indicate that the company will reward women workers with good work performance.

Respondents on item 2, can be explained as follows: 28 respondents $(11.32 \%)$ expressed disagreement, 51 respondents $(20.75 \%)$ expressed disagreement, 169 respondents $(67.92 \%)$ agreed and strongly agreed, with an average value of 3.679. The results of the average value indicate that the company provides space for female workers to develop creativity in completing work.

Respondents on item 3, can be explained as follows: 5 respondents (1.89\%) expressed disagreement, 33 respondents $(13.21 \%)$ expressed disagreement, 210 respondents $(84.91 \%)$ agreed and strongly agreed, with an average value of 4,170 . The average value of the results shows that the company gives trust to female workers in completing work.

Respondents on item 4, can be explained as follows: 14 respondents (5.66\%) expressed disagreement, 37 respondents (15.09\%) stated they did not agree, 197 respondents $(79.25 \%)$ agreed and strongly agreed, with an average value of 4,264 . The results of the average score indicate that to improve the career of the company encourages all female workers to work as well as possible.

Respondents on item 5, can be explained as follows: 5 respondents (1.89\%) expressed disagreement, 19 respondents $(7.55 \%)$ stated disagreement, 224 respondents $(90.57 \%)$ agreed and strongly agreed, with an average value of 4,189 . The average value of the results shows that the company provides opportunities for advancing opportunities for all female workers.

Hypothesis testing Variable $\mathrm{X}$ workload has a significant positive direct effect on $\mathrm{Y}$ is career development.

Table 3. The fit model of the research results

\begin{tabular}{lc}
\hline APC $=0.129$ & $\mathrm{P}=0.019$ \\
\hline ARS $=0.017$ & $\mathrm{P}=0.017$ \\
AVIF $=1.000$ & Good if $<5$ \\
\hline
\end{tabular}


The P value for APC 0.019 and ARS 0.017 is stated to be smaller than 0.05 , which means significant, whereas for VIF value of 1,000 less than 5, it can be interpreted that this model is fit without multicollinearity in testing.

Table 4. Test of Path Coefficients

\begin{tabular}{lcc}
\hline & $\mathrm{X}$ & $\mathrm{Y}$ \\
\hline $\mathrm{X}$ & & \\
$\mathrm{Y}$ & 0.129 & \\
\hline
\end{tabular}

The results of the workload testing on career development are known to be path coefficients of 0.129 , which means that it has a positive effect, while the p-value 0.034 value is smaller than 0.05 , meaning that the workload testing results on career development have a significant positive effect.

Table 5. Test of $P$ values

\begin{tabular}{ccc}
\hline & $\mathrm{X}$ & $\mathrm{Y}$ \\
\hline $\mathrm{X}$ & & \\
$\mathrm{Y}$ & 0.034 & \\
\hline
\end{tabular}

R-squared value of 0.017 or $2 \%$ means that the relationship between $\mathrm{X}$ and $\mathrm{Y}$ directly has a very small effect because only $2 \%$. The reliability composite value is 0.809 and $0.869>0.8$ has a high relibilita influence. The cronbach alpha value serves to strengthen the reliability value with sig. > 0.6 while in this study amounted to 0.644 and $\mathrm{Y}$ of 0.810 .

Table 6. Latent Variable Coefficients Test

\begin{tabular}{lcc}
\hline & $\mathrm{X}$ & $\mathrm{Y}$ \\
R-squared & & 0.017 \\
Composite reliability coefficients & 0.809 & 0.869 \\
Cronbach's alpha coefficients & 0.644 & 0.810 \\
Full collinearity VIFs & 1.012 & 1.012 \\
Q-squared coefficients & & 0.018 \\
\hline
\end{tabular}

\subsection{Discussion}

From the analysis of the description of workload variables perceptions of respondents' answers to statement items on research variables in the questionnaire distributed to respondents. As shown in table 1 above, shows that the highest perception of factory workers regarding workload is located on the indicator, to meet the target company I am required to work overtime. This is indicated by the average value of employees agreeing and strongly agree at 4.019. Targets are always needed in the world of work, without targets, the direction and 
purpose of the company becomes unclear. The targets given to employees in fact actually provide many benefits. Among others, making employee work faster, rhythm work more regularly, learning more responsibly, and making a team more effective at work.

Table 2 above, shows that the highest perception of factory workers regarding career development is that it lies in the indicators, to improve the career of the company encourages all employees to work as well as possible. This is indicated by the average value of employees agreeing and strongly agree at 4.264. Company management needs to encourage employees to improve their abilities, for example through training programs, taking courses or adding degrees, meaning that they take advantage of opportunities to grow. This is useful for both the personnel department in developing internal human resources and for achieving employee career plans.

From the data analysis, the results of workload testing on career development have a significant positive effect, with an R-squared value of 0.017 or $2 \%$, meaning that the workload variable of female workers with direct development is very small because only $2 \%$ is affected by other variables.

There are nine factors that influence employee career development, namely: employee and organizational relations; employee personnel; external factors; politics in the organization; reward system; number of employees; organization size; organizational culture; and type of management [15]. Other factors that influence career development are, company policy, educational background, training, work experience, loyalty to the organization and the flexibility of social relationships and relationships [16].

So there are so many factors that influence a person's career development. Personal development in the context of employees in a company is synonymous with career development. Because a career is all work carried out by employees during the period of work or duties that provide continuity, regularity, and value for the life of a person or employee.

Career development basically aims to improve and improve the effectiveness of the work carried out by workers, so that they are increasingly able to provide the best contribution in realizing the organization's business goals. Companies must have data as a reference to determine employee workload, this is very important when deciding something. Do not let decisions made based on estimates or guesses, which results in negative feedback for the company, if the guess is wrong. A small mistake can be big if it continues to do.

By applying the results of the workload analysis, it is highly expected that the company can get a high level of efficiency, especially for the company's Human Resources, and in turn it is also expected to improve employee career development which ultimately increases company productivity.

\section{Conclusions and suggestions}

\subsection{Conclusion}

From the analysis of the description of factory workers in the Surabaya coral reef area, the workload variable indicators that they are willing to work overtime to meet my company's targets are required to be the highest indicator average. And from the analysis of the description of factory workers in the coral reef area of Surabaya Surabaya, variable indicators of career development that the company encourages all employees to work as well as possible the highest average. From the results of hypothesis testing this study proves that the workload on career development has a positive and significant effect. 


\subsection{Suggestion}

Small, medium or large companies need to analyze the workload first to improve the efficiency of human resources. Rigid and closed company management system, the involvement of employees in developing their own career tends to be minimal. Conversely, if the company's management system tends to be open, participatory, and democratic, then the involvement of employees in their career development also tends to develop.

\section{Acknowledgments}

We express our gratitude to the Institute for Research and Community Service of the University of Muhammadiyah Surabaya, the Faculty of Economics and Business, University of Muhammadiyah Surabaya, which has supported and facilitated this research.

\section{References}

[1] Badan Pusat Statistik, 'Hasil Sensus Ekonomi', Jakarta, 2016.

[2] A. Tirtaputra, L. T. Tjie, and F. Salim, 'Persepsi terhadap Beban Kerja dengan Turnover Intention pada Karyawan', J. Psikol., vol. 13, no. 2, pp. 81-91, 2017.

[3] T. H. Handoko, Manajemen Personalia \& Sumber Daya Manusia, 2nd ed. Yogyakarta: BPFE, 2012.

[4] G. Dayona and N. Rinawati, 'Pengaruh Pelatihan Dan Pengembangan Karir Terhadap Employee Engagement Di PT Andalan Finance Indonesia', J. Indones. Membangun, vol. 15, no. 2, pp. 39-61, 2016.

[5] W. Paramita, W. S. Pambudi, and H. Aminah, 'The Impact of Career Development and Workload Toward Employee Job Satisfaction At PT Askrindo Jakarta', JRMSI - J. Ris. Manaj. Sains Indones., vol. 8, no. 1, pp. 39-57, 2017.

[6] Y. Padendenan, 'Pengaruh Kompetensi dan Pengembangan Karir Terhadap Kinerja Pegawai Pada Dinas Pendidikan dan Kebudayaan Kabupaten Sigi', e-Jurnal Katalogis, vol. 5, no. 12, pp. 127-137, 2017.

[7] Y. I. Lestari, 'Sikap Terhadap Pengembangan Karir Ditinjau dari Gender', J. Psikol., vol. 1, no. 2, pp. 120-126, 2015.

[8] A. Massalena and H. Sulistyo, 'Antenseden Pengembangan Karir Di Badan Diklat Provinsi Jawa Tengah', Ekon. Bisnis, vol. 16, no. 1, pp. 27-39, 2015.

[9] T. E. Tandi and I. S. M. Nur, 'Pengaruh Beban Kerja Dan Komunikasiterhadap Kepuasan Kerja Pegawaipada Bandar Udara Kelas Utama Sentani Di Kabupaten Jayapura', Futur. J. Manaj. dan Akunt., vol. 3, no. 2, pp. 172-186, 2002.

[10] G. R. Ngantung, D. P. E. Saerang, and M. Pandowo, 'The Effect of Job Stress, Work Environment and Workload on Employee Turnover Intention (Case Study At PT. Wika Realty Manado)', J. Berk. Ilm. Efisiensi, vol. 15, no. 05, pp. 851-861, 2015.

[11] B. R. Amalia, I. Wahyuni, and E. Ekawati, 'Hubungan Antara Karakteristik Individu, Beban Kerja Mental, Pengembangan Karir Dan Hubungan Interpersonal Dengan Stres Kerja Pada Guru Di SLB Negeri Semarang', J. Kesehat. Masy., vol. 5, no. 5, pp. 68-78, 2017.

[12] S. P. Siagian, Sistem Informasi Manajemen. Jakarta: Bumi Aksara, 2006.

[13] R. C. Reid, J. M. Prausnitz, and B. E. Poling, The Properties of Gases and Liquids, 4th ed. New York: Donneley \& Sons Company, 1987.

[14] Sugiyono, Metode Penelitian Pendidikan: Pendekatan Kuantitatif, Kualitatif, dan RND. Bandung: Alfabeta, 2015.

[15] H. J. N. Utomo and M. Sugiarto, Manajemen Sumber Daya Manusia. Yogyakarta: Ardana Media, 2007. 
[16] D. Egota and E. Sutrisna, 'Analisis Faktor-Faktor Yang Mempengaruhi Pengembangan Karir Karyawan Pada PT Bank Negara Indoneesia (Persero) Tbk Cabang Pekanbaru', Jom FISIP, vol. 2, no. 1, pp. 1-14, 2015. 